\title{
Enhancing growth and yield of crops with nutrient-enriched organic fertilizer at wet and dry seasons in ensuring climate-smart agriculture
}

\author{
Taiwo B. Hammed $^{1} \mathbb{D}$. Elizabeth O. Oloruntoba ${ }^{1}$ - G. R. E. E. Ana ${ }^{1}$
}

Received: 1 August 2018 / Accepted: 1 June 2019 / Published online: 8 June 2019

(c) The Author(s) 2019

\begin{abstract}
Purpose Rapid nutrient depletion in soils is one of the major problems that affect food production and food security in SubSaharan Africa. Studies have linked the growth of food crops with seasonal variation and differences in weather conditions. This study was conducted to assess the effects of various organic fertilizer formulations (OFFs) on the growth and yield of selected crops (Zea mays L.; Glycine max, TX 114 and Dioscorea rotundata Poir) during rainy and dry seasons to ensuring climate-smart agriculture.

Methods The OFFs used were plant-based (PB), animal-based (AB), rock-based (RB), organic mixture (OM-mixture of PB, $\mathrm{AB}$ and $\mathrm{RB}$ ), synthetic/chemical (SC) while ordinary compost without fortification served as control. Effects of OFFs on growth parameters (number of leaves, plant height, stem girth, leaf area, and crop yield) of maize, yam and soybeans were assessed in plot experiments across the two seasons.

Results The RB gave highest growth performances in maize and soybean plots at both seasons when applied at $2.5 \mathrm{t} \mathrm{ha}^{-1}$. It also improved yam growth when applied at $2.5 \mathrm{t} \mathrm{ha}^{-1}$ (rainy season) and $3.0 \mathrm{t} \mathrm{ha}^{-1}$ (dry season) more than any other fertilizer. The largest yield of maize in the dry season was obtained from plots with PB at $2.0 \mathrm{t} \mathrm{ha}^{-1}$. The AB at $2.0 \mathrm{t} \mathrm{ha}^{-1}$ gave the largest soybean yield in the rainy season.

Conclusions Organic fertilizers enriched especially with rock-based and plant-based materials have the potential to ameliorate the threat of climate change and seasonal variation to food security.
\end{abstract}

Keywords Organic fertilizer formulations $\cdot$ Climate-smart agriculture $\cdot$ Natural fortifiers $\cdot$ Growth parameters $\cdot$ Seasonal variation

\section{Introduction}

The importance of agriculture to Nigeria's economy is currently at the center stage of national attention as farming is the main source of livelihood for over $70 \%$ of households in the country. In 2008, agriculture contributed $42 \%$ of the country's GDP (FMARD 2010), which was significantly higher than the $18 \%$ derived from petroleum and natural gas production. However, the country's promising agricultural potential has not been realized and low fertilizer use is a major factor contributing to the stagnant agricultural productivity in Nigeria (FMARD 2010). The compost, which

Taiwo B. Hammed

hammetab2003@yahoo.co.uk

1 Department of Environmental Health Sciences, Faculty of Public Health, College of Medicine, University of Ibadan, P. O. Box 20593 UI HO, Ibadan, Nigeria is an organic fertilizer and an alternative soil amendment, is not very popular among the farmers because of its slower nutrient release potential and bulkiness. A large quantity of organic fertilizer must be applied to crops for effective results, due to low nutrient composition (Akanbi et al. 2007). Therefore, there is an urgent need to improve the quality of organic-based fertilizers for food security and environmental protection in Nigeria. However, over-dependence on expensive inorganic fertilizers may have serious environmental health hazards, such as water pollution and increased production of greenhouse gases, leading to global climate change (Arisha and Bardisi 1999) and eutrophication of water bodies that can cause algal bloom and production of toxins.

Fertilizers are broadly divided into organic (composed of enriched organic matter-plant or animal), or inorganic (composed of synthetic chemicals and/or minerals) (Heinrich 2000) types. By definition, the term 'fertilizer' refers to a soil 
amendment that guarantees the minimum percentages of nutrients (at least the minimum percentage of nitrogen, phosphate, and potash). An "organic fertilizer" refers to fertilizer derived from non-synthetic organic materials, including plant and animal by-products, rock powders, seaweed, inoculants, sewage sludge, animal manures, and plant residues (Benton and Jones 2012) produced through the process of drying, cooking, composting (Dadi et al. 2019), chopping, grinding, fermenting (Mario et al. 2019) or other methods (Thanaporn and Nuntavun 2019). Organic and inorganic fertilizers have been used for many centuries (Erisman et al. 2008), whereas chemically synthesized inorganic fertilizers were only widely developed during the industrial revolution. Thus, increased understanding and use of fertilizers were important parts of the pre-industrial British Agricultural Revolution and the industrial green revolution of the 20th century.

Seasonal variation and changes in weather conditions should predict the performance of microbes on bio-mineralization of organic fertilizer (Gaofei et al. 2010; John et al. 2018) and, consequently, agronomic development of crops. Knowledge of different organic fertilizer responses to seasonal variation will help in climate change resilient and climate-smart agriculture. According to Eghball (2002), compost application in excess of crop requirements can last for several years in the soil since only a fraction of nitrogen and other nutrients in compost become available in the first year after application. Previous studies could not identify the most suitable organic fertilizer for specific crops during each planting season (Dadi et al. 2019; Madhumita and Ashalata 2019; Najla et al. 2018). Zerihun and Haile (2017) tested the effect of organic and inorganic fertilizers on the yield of two soybean varieties and found out that the response of soybean varieties to applied fertilizers was significantly affected by rainfall and its geographical distribution at the two seasons. In another study, Mukhtar et al. (2010) analyzed characters of sweet potato varieties grown at varying levels of organic and inorganic fertilizer during the wet seasons of 2004 and 2005. They concluded that application of organic fertilizer increased the yield of sweet potato in both years. Specifically, this study was conducted to test the effects of different organic fertilizer formulations (OFFs) on cereal (maize), legume (soybean) and tuber (yam) crops during the two seasons (dry and rainy seasons) in terms of agronomic performances, residual soil nutrient levels and crop yield after harvesting with the aim of mitigating climate-induced drought and threat to global food security.

\section{Materials and methods}

\section{Description of the study area}

Ibadan has been the center of administration of the old Western Region since the days of the British colonial rule, and parts of the city's ancient protective walls still stand to this day. The principal inhabitants of the city are Yoruba people. Ibadan experiences two seasons-rainy and dry. The rainy season runs from April through October, with temperature ranges from 23.1 to $27.0^{\circ} \mathrm{C}$ and rainfall that ranges from 0.0 to $338.8 \mathrm{~mm}$ in 2005 . The dry season extends from November through March. Ibadan Southwest Local Government Area (ISLGA), where the study took place, was carved out of the defunct Ibadan Municipal Government (IMG) in 1991. The Administrative Headquarter is located at Oluyole Estate. It covers a landmass of $133.5 \mathrm{~km}^{2}$ with a population density of 2401 persons per square kilometer. The 2010 estimated population for the ISLGA was projected at 320,536 people, using a growth rate of $3.2 \%$ from 2006 census. Figure 1 describes meteorological data in Ibadan in 2012 when this study was carried out.

\section{Study design and data collection procedure}

A randomized complete block design (RCBD) with three replicates was conducted in plot experiments. The main plots were for three staple crops selected for the studymaize (Zea mays L.), soybean (Glycine max; TX 114) and yam (Dioscorea rotundata Poir) while five different OFFs at three levels of applications-2.0 $\mathrm{t} \mathrm{ha}^{-1}, 2.5 \mathrm{t} \mathrm{ha}^{-1}$ and $3.0 \mathrm{t} \mathrm{ha}^{-1}$ and control plot, applied with ordinary compost without formulation formed subplots. The compost was produced by mixing vegetable waste with cow intestinal waste in ratio 3:1, followed by wetting and turning till maturity (Hammed et al. 2011). All the organic fortifiers were also heaped up, composted and air-dried. The formulation was based on initial chemical analyses of all the fortifiers with the assumption that the OFFs should have minimum primary macronutrient values $(P=2.5 \%$ and $N=3.5 \%)$, in accordance with the national quality standard (Otu et al. 2014). The OFFs included plant-based (PB), animal/human-based (AB), rock-based (RB) and organic-based (OM) fertilizers. The $\mathrm{PB}$ composed of $26.07 \%$ neem, $12.50 \%$ cottonseed and $61.43 \%$ compost; AB comprised $29.40 \%$ cow blood, 11.37 bone and $59.23 \%$ compost, and Rock-based comprised $26.6 \%$ hair, $8.8 \%$ phosphate rock and $64.6 \%$ compost. Organic-based fertilizer was obtained by mixing $\mathrm{PB}, \mathrm{AB}$, and $\mathrm{RB}$ in the same proportion. In addition to OFFs, synthetic chemical (SC) fertilizer produced from urea and single super-phosphate $(5.56 \%$ urea $+8.33 \%$ phosphorus $+86.11 \%$ compost) was also used as a chemical counterpart in this study. Urea was sourced from AFCOTT Nig. LTD, Lagos, Nigeria; it contained $45 \% \mathrm{~N}$ per $50 \mathrm{~kg}$ bag. The SSP was sourced from Fertilizer and Chemical LTD., Kaduna, Nigeria and contained $18 \% \mathrm{P}_{2} \mathrm{O}_{5}$.

A $30 \times 30 \mathrm{~m}^{2}$ of land along Jericho-Alesinloye road, behind the facility, was cleared for farm trials. The land was tilled to prepare maize and soybean beds and ridges for 

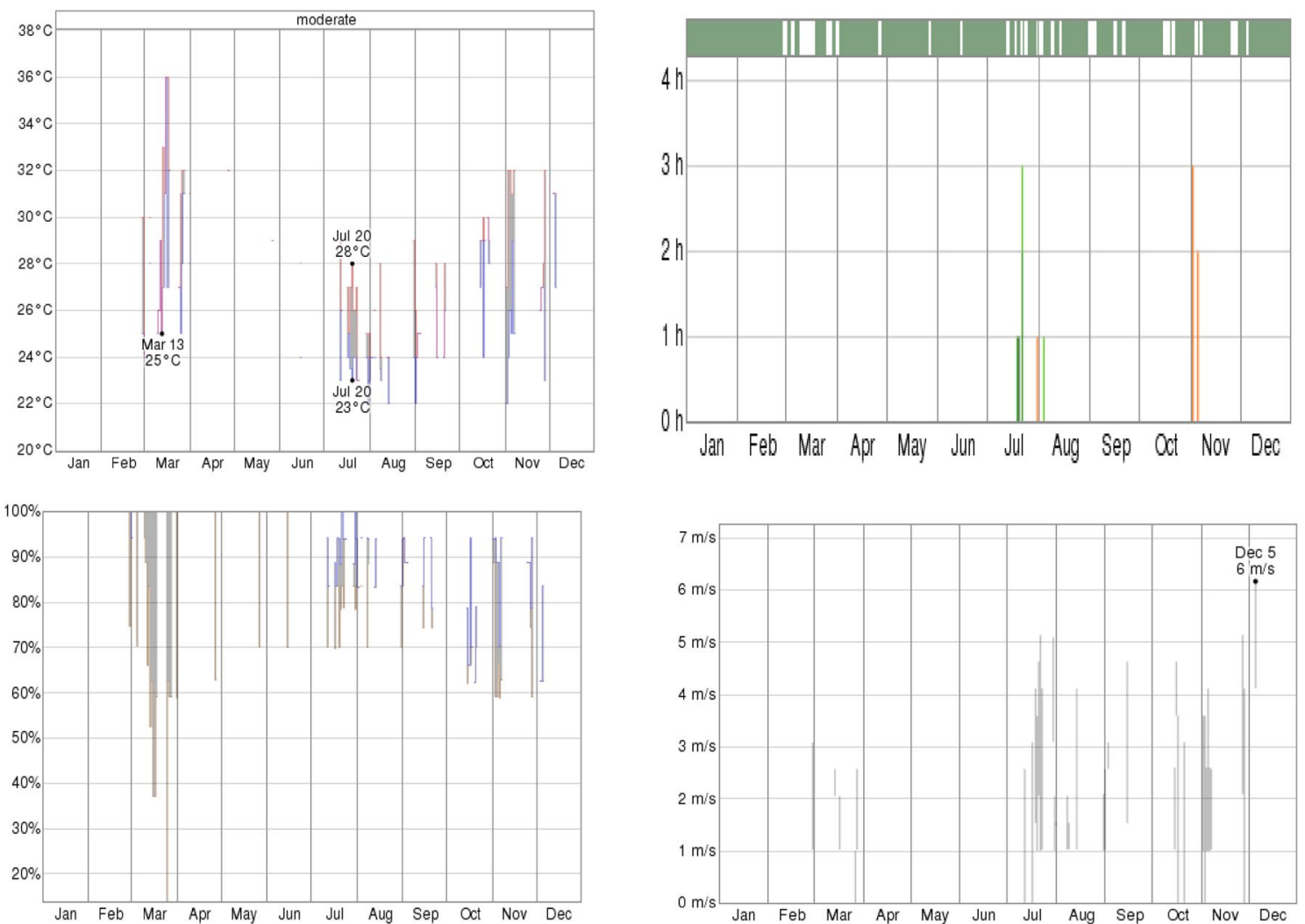

Fig. 1 Top left-temperature condition in Ibadan in the year 2012; top right-precipitation condition in Ibadan in the year 2012; bottom lefthumidity condition in Ibadan in the year 2012; bottom right—-wind speed condition in Ibadan in the year 2012

yam. A subplot was $1 \times 1 \mathrm{~m}^{2}$ and in the maize and soybean subplots, each of the treatments and control subplots was planted with crops in $3 \times 3$ factorial design with three replicates. In the yam subplot, $2 \times 3$ factorial was used. A total of 72 yam tubers (each yam weight $0.55 \mathrm{~g}$ ) were planted on the yam ridges. Thrash removed from the ground during the clearing was used as mulch. A distance of $45 \mathrm{~cm}$ was maintained between the crops planted. Thinning and transplanting of maize from three stands to one was carried out 2 weeks after planting and before fertilizer application. Fertilizer application to maize and soybean was done, using the ring method $-3 \mathrm{~cm}$ deep and $5 \mathrm{~cm}$ away from stem 2 weeks after germination. Fertilizer was applied to yam in ring form under the mulch, a month after planting and at the first appearance of a shoot.

Soil samples for residual effect were collected at depth of $10 \mathrm{~cm}$ into the soil from maize, soybean and yam plots after harvesting. Grab samples were collected from each replicate, which were then pooled to form composite samples. Thinning and transplanting of maize from three stands to one was carried out 2 weeks after planting and before fertilizer application. All the measurements were taken at a week interval and the exercise continued for 11 weeks, maturity period for the crops. Standard laboratory methods as described by Motsara and Roy
(2008) were followed to appraise residual nutrients and heavy metal concentration of fertilizers in the composite samples, using the Eq. 1. Agronomic data were observed viz. number of leaves, by counting; plant height, leaf area, and stem girth (in centimeters) by metric rule; and crop yield by weighing scale. Maize leaf area was calculated thus: $L \times B \times 0.745$ (Agboola 1990). Plant height was measured as the distance from the base of the plant to the height of the first tassel branch and ear height as the distance to the node bearing the upper ear (Badu-Apraku et al. 2010). The entire farm plot experiments were carried out during the two seasons-dry and rainy. The sample mean, confidence interval (at 95\%), and percentage composition were computed based on the data obtained from laboratory and field trials. The data were then subjected to analysis of variance (ANOVA) and New Duncan's multiple range test (Duncan 1959) for means separation at 95\% level of probability for the growth and yield parameters. Again, the Pearson's correlation coefficient between the rate of fertilizer application and agronomic data was carried out, using SPSS software version 16 .

Residual nutrient $(\%)=\frac{A-B}{N} \times 100$, 
where $A$ is nutrients in the soil after harvesting, $B$ is soil background nutrient level before planting and $N$ is the nutrient composition of fertilizers.

\section{Results and discussion}

\section{Effect of seasonal variation on agronomic parameters of the test crops}

Of all OFFs tested on the three crops, RB showed the highest effect during both seasons on all the crops. The effects of different rate of application of RB on agronomic parameters of the test crops are shown in Fig. 2. There were more growths in all the maize and yam parameters in the rainy season than those in the dry season. This could probably be due to the fact that organic fertilizer depends on soil microbes, which are living organisms for bio-mineralization, growth conditions, cultural practices, soil characteristics (Below 2001), and seasonal variation and changes in weather conditions should predict the performance of microbes and consequently, the level of bio-mineralization of organic fertilizer. According to Obiokoro (2005), climate is one of the physical factors that determines the nature of the natural vegetation, the characteristics of the soils, the crops that can be grown, and the type of farming that can be practiced in any region. A related study dealt with the response of Dioscorea alata to NPK-Ca, shows that fertilization is affected by differences in weather conditions in the two growing seasons (Hgaza et al. 2010). Maize had the highest response to the RB fertilizer when applied at the rate of $2.5 \mathrm{tha}^{-1}$ at both seasons, and for yam, $2.5 \mathrm{t} \mathrm{ha}^{-1}$ (rainy season) and $3.0 \mathrm{t} \mathrm{ha}^{-1}$ (dry season) were mostly effective. Conversely, soybean showed better agronomic performance in the dry season compared to that in the rainy season, especially when applied at a rate of $2.5 \mathrm{t} \mathrm{ha}^{-1}$. This finding is similar to a previous study conducted by Makinde and Salau (2017) who showed that the application of $2.5 \mathrm{tha}^{-1}$ cassava peel compost fortified with either 25 or $50 \mathrm{~kg} \mathrm{~N} \mathrm{ha}^{-1}$ gave optimum Amaranthus growth with optimum residual soil nutrient contents.

The most important climatic parameters for crop growth and yield are solar radiation, temperature, and rainfall (Ekaputa 2004). Solar radiation determines the thermal characteristics of the environment, namely net radiation, day-length or photoperiod, the air, and soil temperatures (Danjuma 2004). Soil and air temperatures affect the developmental stages more than any other factor (Ayoade 2002). Of the two, soil temperature is a better indicator of energy condition required for crop development and yield than air temperature (Song 2003). In addition, temperature and wind determine the state of soil moisture and the rate of evaporation (Okpemuoghor 2005). In order to determine the optimum microclimatic condition for crops' growth and yield, various soil surface modification systems, such as mulching and ridge construction were used in the plot experiment during this study.
Fig. 2 Effect of different rate of application of RB on agronomic parameters of the test crops. $P H$ plant height, $L A$ leaf area, $S G$ stem girth, $N L$ no. of leaves

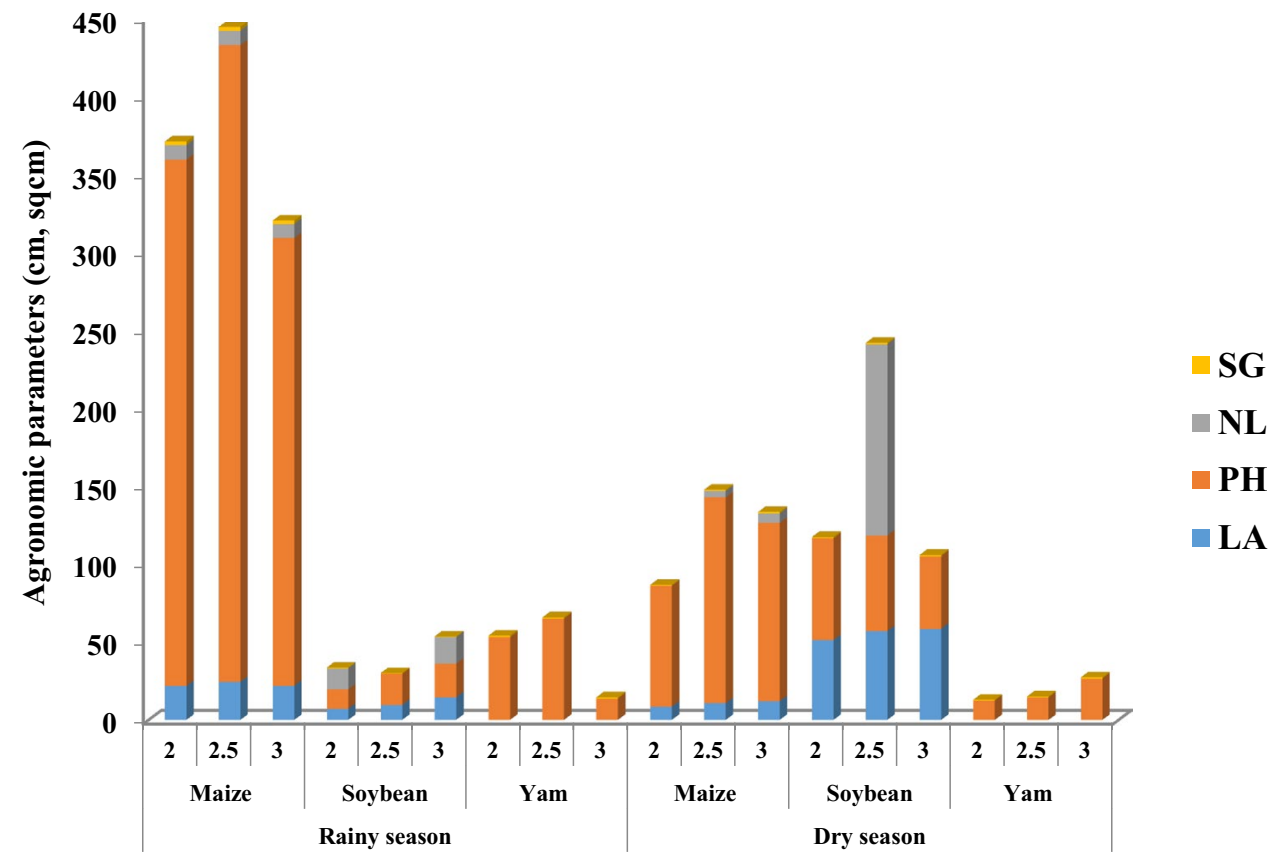

Type of season and rate of application $\left(t \cdot h a^{-1}\right)$ 


\section{Correlation matrix between agronomic parameters for maize and soybean at first and second cropping}

Tables 1, 2, 3 and 4 show the correlation matrices between the agronomic parameters measured in maize and soybean during the rainy and dry seasons. There was a correlation between all agronomic parameters in maize when applied with ordinary compost during the first cropping. Very strong significant correlations were noted between $\mathrm{PH}$ and SG in maize plot applied with SC and PB during the first cropping with $r=0.818$ and $r=0.694$, respectively. In the plots applied with other formulation, no significant correlation existed; a negative correlation was even noted in SG and LA in the plot applied with RB $(r=-0.142)$ and between SG and PH $(r=-0.206)$ in OM plot. A similar situation was observed in the second cropping. However, some parameters exhibited a strong relationship in $\mathrm{RB}$ and $\mathrm{AB}$ plots and some showed a negative relationship in OM plot.

Correlation also existed in the soybean plots among different parameters during the two planting seasons. The observation in soybean parameter correlation was almost in the reverse direction to what obtained in the maize. Some negative correlations were observed in both rainy (NL Vs SG, $r=-0.008$ ) and dry (SG Vs PH: $r=-0.075$ and SG Vs LA: $r=-0.134$ ) seasons in the control plots with ordinary compost. Common to both seasons, LA exhibited a positive and significant relationship with other parameters. The correlation between one parameter and others during the two planting seasons may be a clear indication that a formulation may be chosen for dual or multiple purposes. However, the observation in soybean parameter correlation was almost in the opposite direction to that obtained in the maize. This
Table 1 Correlation matrix between agronomic parameters for maize at first cropping

\begin{tabular}{|c|c|c|c|c|}
\hline Parameters & Plant height & Leaf area & Number of leaves & Stem girth \\
\hline \multicolumn{5}{|c|}{ Ordinary compost $(\mathrm{C})$} \\
\hline Plant height & 1 & & & \\
\hline Leaf area & $0.931 * *$ & 1 & & \\
\hline Number of leaves & $0.825 * *$ & $0.907 * *$ & 1 & \\
\hline Stem girth & $0.696^{*}$ & $0.734^{*}$ & $0.707 *$ & 1 \\
\hline \multicolumn{5}{|c|}{ Synthetic fertilizer (SC) } \\
\hline Plant height & 1 & & & \\
\hline Leaf area & 0.523 & 1 & & \\
\hline Number of leaves & $0.738^{*}$ & 0.437 & 1 & \\
\hline Stem girth & $0.818 * *$ & $0.785^{*}$ & $0.714 *$ & 1 \\
\hline \multicolumn{5}{|l|}{ Plant based (PB) } \\
\hline Plant height & 1 & & & \\
\hline Leaf area & 0.615 & 1 & & \\
\hline Number of leaves & 0.496 & -0.106 & 1 & \\
\hline Stem girth & $0.694 *$ & 0.466 & 0.409 & 1 \\
\hline \multicolumn{5}{|l|}{ Animal based (AB) } \\
\hline Plant height & 1 & & & \\
\hline Leaf area & 0.505 & 1 & & \\
\hline Number of leaves & $0.727 *$ & $0.766^{*}$ & 1 & \\
\hline Stem girth & 0.570 & 0.299 & 0.524 & 1 \\
\hline \multicolumn{5}{|l|}{ Rock based (RB) } \\
\hline Plant height & 1 & & & \\
\hline Leaf area & 0.277 & 1 & & \\
\hline Number of leaves & 0.209 & $0.679^{*}$ & 1 & \\
\hline Stem girth & 0.266 & -0.142 & -0.159 & 1 \\
\hline \multicolumn{5}{|c|}{ Organic mixture $(\mathrm{OM})$} \\
\hline Plant height & 1 & & & \\
\hline Leaf area & 0.216 & 1 & & \\
\hline Number of leaves & 0.435 & 0.116 & 1 & \\
\hline Stem girth & -0.206 & 0.209 & 0.456 & 1 \\
\hline
\end{tabular}

Key: plant height $(\mathrm{cm})$; leaf area $\left(\mathrm{cm}^{2}\right)$; stem girth $(\mathrm{cm})$

*Correlation is significant at the 0.05 level (two-tailed)

**Correlation is significant at the 0.01 level (two-tailed) 
Table 2 Correlation matrix between agronomic parameters for maize at second cropping

\begin{tabular}{|c|c|c|c|c|}
\hline Parameters & plant height & Leaf area & Number of leaves & Stem girth \\
\hline \multicolumn{5}{|c|}{ Ordinary compost $(\mathrm{C})$} \\
\hline Plant height & 1 & & & \\
\hline Leaf area & $0.696^{*}$ & 1 & & \\
\hline Number of leaves & 0.571 & 0.651 & 1 & \\
\hline Stem girth & 0.546 & $0.856^{* *}$ & 0.219 & 1 \\
\hline \multicolumn{5}{|c|}{ Synthetic fertilizer (SC) } \\
\hline Plant height & 1 & & & \\
\hline Leaf area & $0.682 *$ & 1 & & \\
\hline Number of leaves & $0.776^{*}$ & 0.478 & 1 & \\
\hline Stem girth & 0.559 & $0.857 * *$ & 0.580 & 1 \\
\hline \multicolumn{5}{|l|}{ Plant based (PB) } \\
\hline Plant height & 1 & & & \\
\hline Leaf area & $0.976^{* *}$ & 1 & & \\
\hline Number of leaves & $0.917 * *$ & $0.905 * *$ & 1 & \\
\hline Stem girth & $0.765^{*}$ & $0.783 *$ & 0.550 & 1 \\
\hline \multicolumn{5}{|l|}{ Animal based (AB) } \\
\hline Plant height & 1 & & & \\
\hline Leaf area & $0.746^{*}$ & 1 & & \\
\hline Number of leaves & $0.799 * *$ & $0.814 * *$ & 1 & \\
\hline Stem girth & 0.333 & 0.116 & 0.093 & 1 \\
\hline \multicolumn{5}{|l|}{ Rock based (RB) } \\
\hline Plant height & 1 & & & \\
\hline Leaf area & $0.873 * *$ & 1 & & \\
\hline Number of leaves & $0.889 * *$ & $0.928 * *$ & 1 & \\
\hline Stem girth & $0.908 * *$ & $0.905 * *$ & $0.855^{* *}$ & 1 \\
\hline \multicolumn{5}{|c|}{ Organic mixture $(\mathrm{OM})$} \\
\hline Plant height & 1 & & & \\
\hline Leaf area & -0.324 & 1 & & \\
\hline Number of leaves & 0.032 & 0.366 & 1 & \\
\hline Stem girth & -0.203 & 0.501 & 0.453 & 1 \\
\hline
\end{tabular}

Key: plant height $(\mathrm{cm})$; leaf area $\left(\mathrm{cm}^{2}\right)$; stem girth $(\mathrm{cm})$

*Correlation is significant at the 0.05 level (two-tailed)

**Correlation is significant at the 0.01 level (two-tailed) disparity might be a consequence of the specific nature of OFF application to different crops. In general, a good knowledge of correlation among agronomic parameters is required before selecting the type of OFFs to be applied to crops.

Figures 3, 4 and 5 show fresh yields of maize, soybean and yam when applied with different OFFs at the two seasons, respectively. In maize plots, formulations showed more effect on crop yield during the first cropping (rainy) than that in the second (dry) season. However, the yield in maize during the dry season far outweighed that of the rainy season when PB was applied at $2.0 \mathrm{tha}^{-1}$. The formulations mostly showed more effect on the soybean yield during the second (dry) season than that in the first cropping (rainy) season. The PB at rate $2.5 \mathrm{t} \mathrm{ha}^{-1}$ gave the highest yield of soybean at the two seasons while $\mathrm{AB}$ at $2.0 \mathrm{t} \mathrm{ha}^{-1}$ was the best OFF for soybean in the rainy season. Yam has only one season and $\mathrm{OM}\left(3.0 \mathrm{tha}^{-1}\right)$ gave the highest yam tuber yield. This is closely followed by RB $\left(2.0 \mathrm{t} \mathrm{ha}^{-1}\right)$ and $\mathrm{AB}\left(2.5 \mathrm{t} \mathrm{ha}^{-1}\right)$. This observation suggests seasonal specificity for OFFs. There are many research studies on the effect of organic fertilizer modification and crop yield. Loeeke et al. (2004) reported that composted manure increased corn grain yield more than fresh manure. Jayaprakash et al. (2003) conducted a field experiment to determine the effect of organic and inorganic fertilizers on the yield and yield attributes of maize under irrigated condition. Significantly highest grain yield was obtained with application of compost at $2 \mathrm{t} \mathrm{ha}^{-1}$, similar to that obtained for RB during the dry season in this study.

The tuber yield responses to OFF application in this study are contrary to the findings of Sotomayor-Ramirez et al. (2003). The lack of tuber yield responses in their studies might be due to pest and diseases or the closeness 
Table 3 Correlation matrix between agronomic parameters for soybean at first cropping

\begin{tabular}{|c|c|c|c|c|}
\hline Parameters & Plant height & Leaf area & Number of leaves & Stem girth \\
\hline \multicolumn{5}{|c|}{ Ordinary compost (C) } \\
\hline Plant height & 1 & & & \\
\hline Leaf area & $0.787^{*}$ & 1 & & \\
\hline Number of leaves & $0.754^{*}$ & $0.929 * *$ & 1 & \\
\hline Stem girth & 0.514 & 0.008 & -0.008 & 1 \\
\hline \multicolumn{5}{|c|}{ Synthetic fertilizer (SC) } \\
\hline Plant height & 1 & & & \\
\hline Leaf area & $0.913 * *$ & 1 & & \\
\hline Number of leaves & 0.659 & $0.804 * *$ & 1 & \\
\hline Stem girth & $0.868 * *$ & $0.847 * *$ & $0.846^{* *}$ & 1 \\
\hline \multicolumn{5}{|l|}{ Plant based (PB) } \\
\hline Plant height & 1 & & & \\
\hline Leaf area & $0.859 * *$ & 1 & & \\
\hline Number of leaves & $0.895 * *$ & $0.768^{*}$ & 1 & \\
\hline Stem girth & 0.516 & 0.346 & 0.182 & 1 \\
\hline \multicolumn{5}{|l|}{ Animal based (AB) } \\
\hline Plant height & 1 & & & \\
\hline Leaf area & 0.324 & 1 & & \\
\hline Number of leaves & 0.551 & 0.329 & 1 & \\
\hline Stem girth & 0.586 & 0.659 & $0.895 * *$ & 1 \\
\hline \multicolumn{5}{|l|}{ Rock based (RB) } \\
\hline Plant height & 1 & & & \\
\hline Leaf area & $0.883 * *$ & 1 & & \\
\hline Number of leaves & $0.761^{*}$ & $0.878 * *$ & 1 & \\
\hline Stem girth & $0.732^{*}$ & $0.889 * *$ & $0.856^{* *}$ & 1 \\
\hline \multicolumn{5}{|c|}{ Organic mixture (OM) } \\
\hline Plant height & 1 & & & \\
\hline Leaf area & $0.938 * *$ & 1 & & \\
\hline Number of leaves & $0.809 * *$ & $0.890 * *$ & 1 & \\
\hline Stem girth & 0.294 & 0.305 & 0.416 & 1 \\
\hline
\end{tabular}

Key: plant height $(\mathrm{cm})$; leaf area $\left(\mathrm{cm}^{2}\right)$; stem girth $(\mathrm{cm})$

*Correlation is significant at the 0.05 level (two-tailed)

**Correlation is significant at the 0.01 level (two-tailed) of fertilized and non-fertilized plots as the length of roots can reach $5.5 \mathrm{~m}$ (O'Sullivan 2008). Organic manure can serve as an alternative practice to mineral fertilizers (Wong et al. 1999; Naeem et al. 2006) for improving soil structure (Dauda et al. 2008) and microbial biomass (Suresh et al. 2004). Therefore, the utilization of locally produced manures by vegetable production operations may increase crop yields with less use of chemical fertilizer. The use of chemical fertilizers alone to sustain high crop yield has not been quite successful due to the enhancement of soil acidity, nutrient leaching, degradation of soil physical properties, and organic matter status (Nottidge et al. 2005).

\section{Residual potential of chemical contents of organically fortified fertilizers}

As shown in Fig. 6, all the formulations showed residual nutrient potentials, though at varying levels. More quantities of OC were retained in SC plots (for yam and maize) and $\mathrm{K}$ (for all plots) than those in any other plot applied with other formulations. Control (ordinary compost) retained the highest levels of TN and P in the maize, yam, and soybean plots. Retention of TN and P in the maize, yam, and soybean control plots may be due to the fact that the nutrients were not in the form that could be readily absorbed by the plant roots. Additionally, high residual levels of $\mathrm{OC}$ and $\mathrm{K}$ 
Table 4 Correlation matrix between agronomic parameters for soybean at second cropping

\begin{tabular}{|c|c|c|c|c|}
\hline Parameters & Plant height & Leaf area & Number of leaves & Stem girth \\
\hline \multicolumn{5}{|c|}{ Ordinary compost (C) } \\
\hline Plant height & 1 & & & \\
\hline Leaf area & $0.771 *$ & 1 & & \\
\hline Number of leaves & $0.861 * *$ & $0.702 *$ & 1 & \\
\hline Stem girth & -0.075 & -0.134 & 0.024 & 1 \\
\hline \multicolumn{5}{|c|}{ Synthetic fertilizer (SC) } \\
\hline Plant height & 1 & & & \\
\hline Leaf area & 0.500 & 1 & & \\
\hline Number of leaves & $0.881 * *$ & 0.315 & 1 & \\
\hline Stem girth & 0.107 & 0.488 & 0.068 & 1 \\
\hline \multicolumn{5}{|l|}{ Plant based (PB) } \\
\hline Plant height & 1 & & & \\
\hline Leaf area & 0.533 & 1 & & \\
\hline Number of leaves & $0.676^{*}$ & $0.838 * *$ & 1 & \\
\hline Stem girth & $0.793^{*}$ & 0.260 & 0.433 & 1 \\
\hline \multicolumn{5}{|l|}{ Animal based (AB) } \\
\hline Plant height & 1 & & & \\
\hline Leaf area & $0.772^{*}$ & 1 & & \\
\hline Number of leaves & $0.854 * *$ & $0.739^{*}$ & 1 & \\
\hline Stem girth & 0.123 & -0.278 & 0.226 & 1 \\
\hline \multicolumn{5}{|l|}{ Rock based (RB) } \\
\hline Plant height & 1 & & & \\
\hline Leaf area & 0.018 & 1 & & \\
\hline Number of leaves & $0.856^{* *}$ & 0.092 & 1 & \\
\hline Stem girth & -0.042 & $0.698^{*}$ & 0.112 & 1 \\
\hline \multicolumn{5}{|c|}{ Organic mixture $(\mathrm{OM})$} \\
\hline Plant height & 1 & & & \\
\hline Leaf area & 0.037 & 1 & & \\
\hline Number of leaves & -0.231 & 0.406 & 1 & \\
\hline Stem girth & -0.230 & -0.316 & -0.084 & 1 \\
\hline
\end{tabular}

Key: plant height $(\mathrm{cm})$; leaf area $\left(\mathrm{cm}^{2}\right)$; stem girth $(\mathrm{cm})$

*Correlation is significant at the 0.05 level (two-tailed)

**Correlation is significant at the 0.01 level (two-tailed) found in SC and RB may be due to the low level of biomineralization. Among all the OFFs, RB was comparable to $\mathrm{SC}$ in terms of $\mathrm{OC}$ and $\mathrm{K}$ residual levels in maize, soybean and yam plots. In the entire main plots for maize, soybean and yam, all the formulations and control plots showed high percentage residual levels of Mn, especially when applied with SC (maize and yam) and OM (soybean) as shown in Fig. 7. Apart from the Mn, other heavy metals were almost found at zero level. The high values of $\mathrm{Mn}$ were due to its initial levels in the soil and compost used for fortification. Generally, organic fertilizer has a binding site to immobilize heavy metals, leading to the highest values exhibited by SC in maize and yam plots. However, the factor that was responsible for the disparity in the soybean plot is yet to be understood. Additionally, the presence of high molecular weight humic acid generally found in soil with well-decomposed organic matter reduces the bioavailability of heavy metal and its toxicity in plant (Inaba and Takenaka 2005), making them to be retained in the soil.

\section{Conclusion}

Seasonal variation had both negative and positive effects on the agronomic development and yield of the three crops (maize, soybean and yam) applied with different organically fortified fertilizers. Though the negative effects were more paramount especially on maize and yam during the dry season, positive effects noted for some of the fertilizers in either of the seasons should be taken as strategies 
Fig. 3 Fresh yield (mean fruit weight) of maize at first and second cropping seasons. $C$ control, $P B$ plant-based fertilizer, $A B$ animal/humanbased fertilizer, $R B$ rock-based fertilizer, $O M$ organic-based fertilizer (mixture of $\mathrm{PB}, \mathrm{AB}$, and $\mathrm{RB}$ ), $S C$ synthetic chemical fertilizer
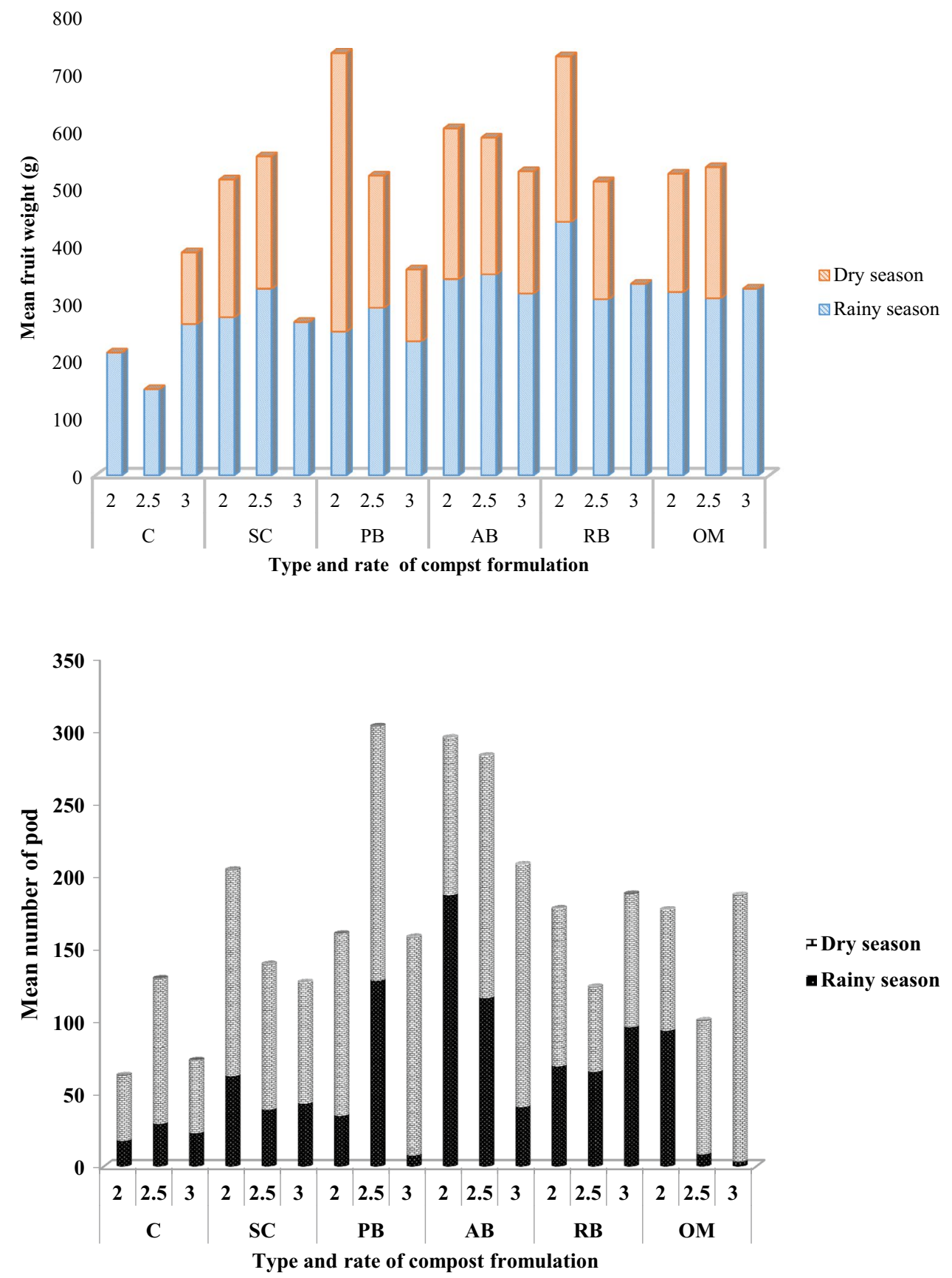

Type and rate of compost fromulation
Fig. 4 Fresh yield (mean pod number) of soybean at first and second cropping seasons. $C$ control, $P B$ plant-based fertilizer, $A B$ animal/humanbased fertilizer, $R B$ rock-based fertilizer, $O M$ organic- based fertilizer (mixture of $\mathrm{PB}, \mathrm{AB}$, and $\mathrm{RB}$ ), $S C$ synthetic chemical fertilizer to alleviate environmental stress on the crops so as to ensure climate-smart agriculture. The rate of application was another key factor that affected performances of the fertilizer on the crops. Rock-based fertilizer (RB) was generally a good promoter of maize and soybean growth at both seasons when applied at $2.5 \mathrm{t} \mathrm{ha}^{-1}$. Additionally, the RB fertilizer was best for yam growth when applied at 2.5 $\mathrm{t} \mathrm{ha}^{-1}$ (rainy season) and $3.0 \mathrm{t} \mathrm{ha}^{-1}$ (dry season). The threat of low yield of maize in the dry season could be offset by applying $\mathrm{PB}$ at $2.0 \mathrm{t} \mathrm{ha}^{-1}$. The $\mathrm{PB}$ at rate $2.5 \mathrm{t} \mathrm{ha}^{-1}$ was good for soybean at the two seasons while $\mathrm{AB}$ at $2.0 \mathrm{t} \mathrm{ha}^{-1}$ was the best OFF for soybean in the rainy season. Fertilizers such as synthetic chemicals (SC) and plant-based (PB) had the potential to simultaneously improve two agronomic characteristics, i.e., plant height and leaf area development. Additionally, both SC and RB retained more 
Fig. 5 Fresh yield (mean weight of tuber) of yam. $C$ control, $P B$ plant-based fertilizer, $A B$ animal/human -based fertilizer, $R B$ rock-based fertilizer, $O M$ organic- based fertilizer (mixture of $\mathrm{PB}, \mathrm{AB}$, and $\mathrm{RB}$ ), $S C$ synthetic chemical fertilizer

Fig. 6 Residual nutrient of fertilizers in maize, soybean and yam plots (\%). $C$ control, $P B$ plant-based fertilizer, $A B$ animal/human-based fertilizer, $R B$ rock-based fertilizer, $O M$ organic-based fertilizer (mixture of $\mathrm{PB}, \mathrm{AB}$, and $\mathrm{RB}$ ), $S C$ synthetic chemical fertilizer
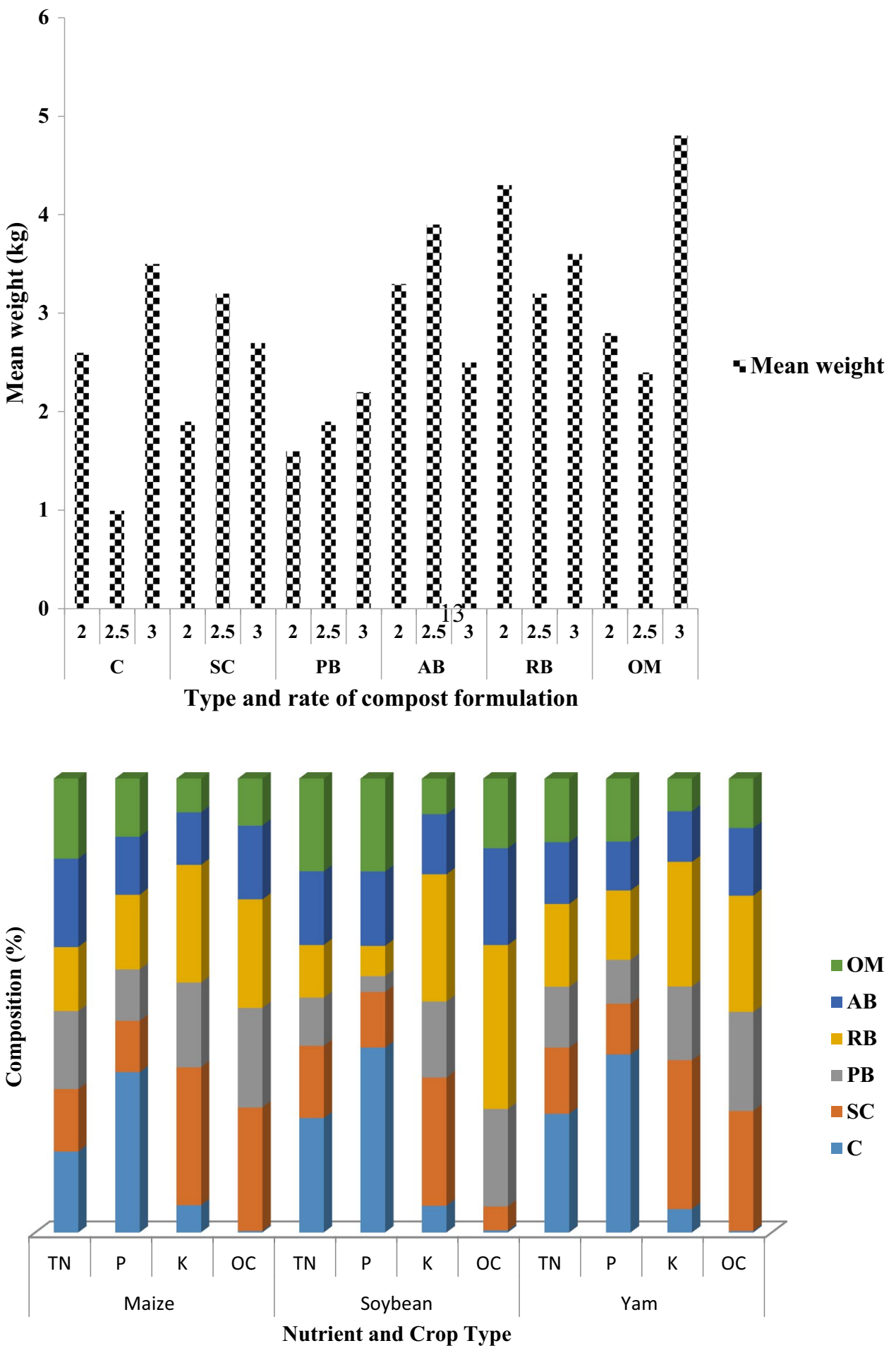

organic carbon and potassium in the soil they were applied to. Manganese was the only heavy metal noticed in the plot with SC (maize and yam) and Organic mixture (soybean), limiting the threat of heavy metal contamination. Therefore, future studies focusing on the bioavailability of heavy metals and their toxicity to crops are recommended. 
Fig. 7 Residual heavy metal concentration of fertilizers in maize, soybean and yam plots (\%). $C$ control, $P B$ plant-based fertilizer, $A B$ animal/humanbased fertilizer, $R B$ rock-based fertilizer, $O M$ organic-based fertilizer (mixture of $\mathrm{PB}, \mathrm{AB}$, and RB), SC synthetic chemical fertilizer

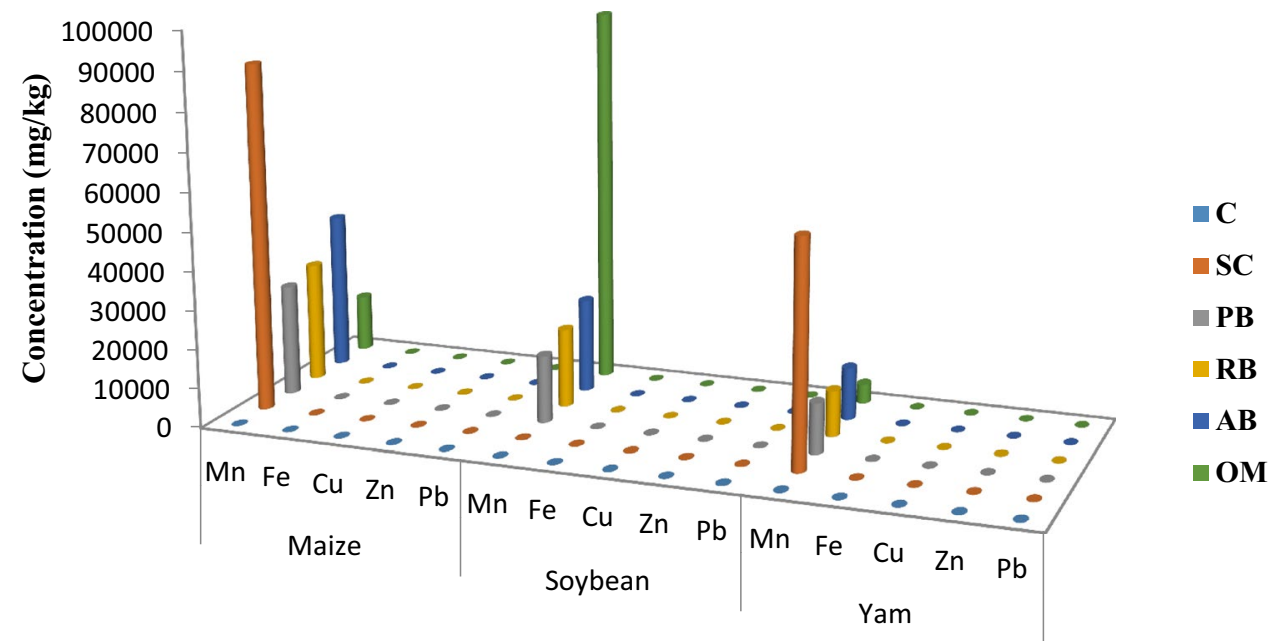

Heavy metal and crop type
Open Access This article is distributed under the terms of the Creative Commons Attribution 4.0 International License (http://creativeco mmons.org/licenses/by/4.0/), which permits unrestricted use, distribution, and reproduction in any medium, provided you give appropriate credit to the original author(s) and the source, provide a link to the Creative Commons license, and indicate if changes were made.

\section{References}

Agboola AA (1990) Organic matter and soil fertility management the humid tropics of Africa. Organic matter management and tillage in humid and sub-humid Africa. In: IBSRAM Proceedings: Bangok, Thailand, vol 10, pp 231-243

Akanbi WB, Adebayo TA, Togun OA, Adeyeye AS, Olaniran OA (2007) The use of compost extract as foliar spray nutrient source and botanical insecticide in Telfairia occidentalis. World $\mathrm{J}$ Agric Sci 3(5):642-652

Arisha HM, Bardisi A (1999) Effect of mineral fertilizers and organic fertilizers on growth, yield and quality of potato under sandy soil conditions. Zagazig J Agric Res 26:391-405

Ayoade JC (2002) Agro climatology. Vantage Publishers, Ibadan, pp 129-137

Badu-Apraku B, Menkir A, Ajala SO, Akinwale RO, Oyekunle M, Obeng-Antwi K (2010) Performance of tropical early-maturing maize cultivars in multiple stress environments. Can J Plant Sci 90:1-22. https://doi.org/10.1017/S0021859611000761

Below EF (2001) Nitrogen metabolism and crop productivity. In: Pessarakli M (ed) Handbook of plant and crop physiology. University of Arisona, Tucson, pp 345-401

Benton J, Jones J (2012) Inorganic chemical fertilizers and their properties in plant nutrition and soil fertility manual, 2nd edn. CRC Press, Boca Raton, pp 20-23

Dadi D, Daba G, Beyene A, Luis P, Van der Bruggen B (2019) Composting and co-composting of coffee husk and pulp with sourceseparated municipal solid waste: a breakthrough in valorization of coffee waste. Int J Recycl Org Waste Agric. https://doi. org/10.1007/s40093-019-0256-8

Danjuma BO (2004) Comparison of soil physico-chemical characteristics of different tillage types in North-eastern Nigeria. J Agric Environ 2(1):1-16
Dauda SN, Ajayi FA, Ndor E (2008) Growth and yield of water melon (Citrullus lanatus) as affected by poultry manure application. $\mathrm{J}$ Agric Soc Sci 4:121-124

Duncan RB (1959) Multiple range and multiple F-tests. Biomedics $2: 1-42$

Eghball B (2002) Soil properties as influenced by phosphorus- and nitrogen -based manure and compost applications. Agron J 94:128-135

Ekaputa UN (2004) Agricultural systems. UNIK Publishers, Port Harcourt, pp 126-134

Erisman JW, Sutton MA, Galloway J, Klimont Z, Winiwarter W (2008) How a century of ammonia synthesis changed the world. Nat Geosci 1(10):636E. https://doi.org/10.1038/ngeo325

Federal Ministry of Agriculture and Rural Development (FMARD). 2010. Blueprint on agriculture and rural development. A Presentation to the National Economic Management Team by the Honourable Minister of Agriculture and Rural Development, Abuja, Nigeria. http://soilsnigeria.net/Publications/Others/FertilizerPolic yforNigeria.pdf. Accessed 13 Jan 2018

Gaofei G, Zhaojun L, Fenliang F, Guixin C, Zhenan H, Yongchao L, Gaofei G, Zhaojun L, Fenliang F, Guixin C, Zhenan H, Yongchao L (2010) Soil biological activity and their seasonal variations in response to long-term application of organic and inorganic fertilizers. Plant Soil 326:31-44. https://doi.org/10.1007/s1110 4-009-0186-8

Hammed TB, Soyingbe AA, Adewole DO (2011) An abattoir waste water management through composting: a case study of Alesinloye waste recycling complex. Int J Int Soc Sci 6(2):67-78. https ://doi.org/10.18848/1833-1882/CGP/v06i02/52024

Heinrich W (2000) Scherer "fertilizers" in Ullmann's encyclopedia of industrial chemistry. Wiley-VCH, Weinheim, pp 122-125

Hgaza VK, Diby LN, Assa A, Ake S (2010) How fertilization affects yam (Dioscorea alata L.) growth and tuber yield across the years. African J Plant Sci 4.3:053-060. https://doi. org/10.2174/1874294701105010014

Inaba S, Takenaka C (2005) Effects of dissolved organic matter on toxicity and bioavailability of copper for lettuce sprouts. Environ Int 31:603-608. https://doi.org/10.1016/j.envin t.2004.10.017

Jayaprakash TC, Nagalikar VP, Pujari BT, Setty RA (2003) Effect of organic and inorganic on yield and yield attributes of maize under irrigation. Karnataka J Agric Sci 16:451-453 
John F, Sean S, Bin Z, Tingting A, Jiubo P, Jie Z, Jingkuan W (2018) How soil bacterial communities with seasonal variation respond differently to long-term fertilization and plastic film mulching. Pol J Environ Stud 27(4):1483-1495. https://doi.org/10.15244 $/$ pjoes/76889

Loeeke TD, Liebman M, Cambbardella CA, Richard TL (2004) Corn response to composting and time of application of solid swine manure. Agron J 96:214-223

Madhumita G, Ashalata D (2019) Assessment of crop growth, soil properties and crop yield in an upland acidic soil with inorganic fertilizer blended with organic amendments in summer rice cropping seasons. Int J Recycl Org Waste Agric. https:// doi.org/10.1007/s40093-019-0252-z

Makinde EA, Salau AW (2017) Fortified cassava peel compost amendment for Amaranthus: influence on plant growth, nutrients uptake and on soil nutrient changes. J Plant Nutr 40(5):645-655. https:// doi.org/10.1080/01904167.2016.1245328

Mario AHC, Catalino JLC, Nereida RO, Joel VV, Ariadna LG, Gustavo LR (2019) Nutrient content of fermented fertilizers and its efficacy in combination with hydrogel in Zea mays L. Int J Recycl Org Waste Agric. https://doi.org/10.1007/s40093-019-0248-8

Motsara MR, Roy RN (2008) Guide to laboratory establishment for plant nutrient analysis, 19th edn. FAO fertilizer and plant nutrition bulletin, Rome, pp 42-88

Mukhtar AA, Tanimu B, Arunah UL, Babaji BA (2010) Evaluation of the agronomic characters of sweet potato varieties grown at varying levels of organic and inorganic fertilizer. World J Agric Sci 6(4):370-373

Naeem M, Iqbal J, Bakhsh MAA (2006) Comparative study of inorganic fertilizers and organic manures on yield and yield components of mungbean (Vigna radiat L.). J Agric Soc Sci 2:227-229. https://doi.org/10.5897/AJAR2017.12675

Najla D, Safaben A, Amin Z, Faouzi H, Bouthaina A, Mohandes D (2018) The challenge of using date branch waste as a peat substitute in container nursery production of lettuce (Lactuca sativa L.). Int J Recycl Org Waste Agric. https://doi.org/10.1007/s4009 3-018-0221-y

Nottidge DO, Ojeniyi SO, Asawalam DO (2005) Comparative effect of plant residues and NPK fertilizer on nutrient status and yield of maize (Zea mays L.) in a humid ultisol. Niger J Soil Sci 15:1-8. https://doi.org/10.4314/njss.v15i1.37439

Obiokoro OG (2005) Agro meteorology. Dunkwu Publishers, Onitsha, pp 24-30

Okpemuoghor ER (2005) Physical Environment. Dosumu Press, Lagos, pp 152-176

O'Sullivan JN (2008) Root distribution of yam (Dioscorea alata) determined by strontium tacer. Exp Agric 44:223-233. https:// doi.org/10.1017/S0014479708006339

Otu WI, Idiong CI, Nsikan EB, Ekaette SU (2014) Food security and productivity of urban food crop farming households in Southern Nigeria. Agric Sci 2(3):01-12

Song AB (2003) The impact of modified physical environment on the yield of yellow and water yams in the middle belt of Nigeria. $J$ Agric Environ 1(2): 14-22

Sotomayor-Ramirez D, Gonzales-Velez A, Roman-Paoli E (2003) Yam (Dioscorea spp) response to fertilization in soils of semiarid southern coast of Puerto Rico. J Agric Univ P R 87(3):91-103

Suresh KD, Sneh G, Krishn KK, Mool CM (2004) Microbial biomass carbon and microbial activities of soils receiving chemical fertilizers and organic amendments. Arch Agron Soil Sci 50:641-647

Thanaporn P, Nuntavun R (2019) Liquid organic fertilizer production for growing vegetables under hydroponic condition. Int J Recycl Org Waste Agric. https://doi.org/10.1007/s40093-019-0252-z

Wong JWC, Ma KK, Fang KM, Cheung C (1999) Utilization of manure compost for organic farming in Hong Kong. Bio-resour Technol 67:43-46

Zerihun A, Haile D (2017) The effect of organic and inorganic fertilizers on the yield of two contrasting soybean varieties and residual nutrient effects on a subsequent finger millet crop. Agronomy 7(2):42-55. https://doi.org/10.3390/agronomy7020042

Publisher's Note Springer Nature remains neutral with regard to jurisdictional claims in published maps and institutional affiliations. 